\title{
Short communication: Savanna-forest boundary on Mount Rinjani, Lombok Island, West Nusa Tenggara, Indonesia
}

\author{
SUTOMO $^{1, \boldsymbol{v}}$, EDDIE VAN ETTEN ${ }^{2}$, RAJIF IRYADI ${ }^{1}$ \\ 1"Eka Karya" Bali Botanic Gardens, Research Centre for Plant Conservation and Botanic Garden, Indonesian Institute of Sciences. Candikuning, Baturiti, \\ Tabanan 82191, Bali, Indonesia. Tel.: +62-368-2033170, 2033170, Fax. +62-368-2033171, `email: tommo.murdoch@gmail.com, \\ masrajifgeo@gmail.com \\ ${ }^{2}$ Edith Cowan University. 270 Joondalup Drive, Joondalup, WA 6027, Australia
}

Manuscript received: 8 May 2020. Revision accepted: 13 January 2021.

\begin{abstract}
Sutomo, van Etten E, Iryadi R. 2021. Short communication: Savanna-forest boundary on Mount Rinjani, Lombok Island, West Nusa Tenggara, Indonesia. Biodiversitas 22: 726-731. Seasonally dry tropical forests tend to be bordered by or are mixed with savanna ecosystems. This research investigates the location and nature of forest-savanna boundary on Mt. Rinjani and hypothesizes on potential causes of such boundary formation. The field survey locations were based on MODIS burnt area data. We made 30 plots (50 x $50 \mathrm{~m}$ ) established along transects to obtain vegetation and environment data across boundaries. For data analysis, we use community correspondence index (CCI), vegetation composition using Importance Value Index (IVI), and Analysis of Similarity (ANOSIM) to detect differences in floristic and environmental characteristics across boundaries. Species composition in the transition zone (based on highest IVI results) comprises Ficus septica, Macaranga tanarius, Lindera sp., Engelhardia spicata, Saurauria sp., Rytidosperma penicillatum, and Athyrium sp. The Non-Metric Multi-Dimensional Scaling (NMDS) based on environmental data showed clear separation between savanna and forest, although boundaries were floristically similar to forest. Micro- and macro-environmental factors, as well as, fire disturbances, are also important features of the forest-savanna boundary on Mt. Rinjani. We present evidence of boundary dynamics in the form of forest advance on the Mt. Rinjani south-west slope.
\end{abstract}

Keywords: Boundary, savanna, similarity, transition, turnover

\section{INTRODUCTION}

In many parts of the tropical and sub-tropical world, landscapes comprise both forest and savanna vegetation. Tropical rain forests are generally the most famous because of their dense structure and high species diversity of both flora and fauna, but half of the global tropics have a seasonally dry climate which is home to dry forests and savannas (Pennington et al. 2018). Up to now, limited attention has been given to the savanna despite it being a widespread and vital ecosystem that supports a fascinating diversity of plant strategies to cope with stress and disturbances including fire, drought, herbivory (including iconic mega-fauna), and human interaction (Pennington et al. 2018; Porensky et al. 2013). Savannas in Indonesia, especially those which exist at high elevation such as on Mount Tambora and Mount Rinjani, are related to volcanic activity and associated early post-eruption successional stages. Succession is a central concept in ecology and the phenomenon of changes in species composition over time has captured the interest of ecologists and naturalists for centuries (McLean 1919; Smith 1914; Walker et al. 2007). Plant species establishment and composition changes in a newly formed substrate with no biological legacy are known as primary succession, while secondary succession refers to the species changes in a habitat with relatively intact soil following a disturbance (Walker and del Moral
2003). Savanna is considered as the realm of the arrested succession stage in terms of primary successional stage following volcanic disturbances whereas forest is seen as the climax of the succession (Sutomo 2013; Zahawi and Augspurger 1999).

The physical environment and vegetation structure where forest and savanna meet are typically different from those of both forest and savanna. This different vegetation type of the mixed area between forest and savanna can be geographically distinct when viewed from a distance (eg aerial photographs or satellite imagery) and share similar components, namely a boundary or transitional zone between these two ecosystems. Transitional zones between savanna and forest may be gradual and wide reflecting gradients in key environmental features, such as slope and soil features (commonly known ecoclines), or maybe relatively narrow reflecting spatially abrupt environmental discontinuities (such as a dramatic change in geology) which lead to more distinct boundaries between ecosystems known as ecotones (van der Maarel 1990). Disturbances such as fire operating within the transition zone can create sharper boundaries between ecosystems (van Etten 1987; Torello-Raventos et al. 2013).

In many places, Seasonally Dry Tropical Forests (SDTFs) tend to border by or are mixed with savanna ecosystems and hence these areas feature clearly visible transitional zones (Pennington et al. 2018). Generally, 
forest has different characteristics compared to savanna. Forest generally has dense tree cover, absence of grasses, a cool, humid microclimate, and infrequent and or mild fire. In contrast, savannas generally have sparse tree cover, hot, dry, and windy microclimates, and frequent fire (Hoffmann et al. 2012). Although we know much about these different characteristics in these two ecosystems, the knowledge regarding conditions of the boundary between these ecosystems is inadequate especially in explaining the different types, their formation, and their dynamic nature.

Determining where transitional zone occurs and how and why their vegetation characteristics change over time has long been a fertile ground for debate (Adejuwon and Adesina 1992). Investigations of vegetation boundaries will aid in revealing the limiting factor(s) that sustain or expand one ecosystem over another (forest or savanna). Savannas cannot be managed without knowledge and understanding of what factors drive their formation and what factors are responsible for maintaining their condition as savanna. Intermixing and coexistence of SDTF and savannas are also clearly seen in Mexico and in the Brazilian Cerrado (Gardner 2006; Pérez-García and Meave 2006; Mews et al. 2014; Klink 2014). Savannas and SDTF are often seen to form landscape mosaics, and a small distinction in factors such as soil, topography, disturbance type, and climate can resolve whether savanna or dry forest will arise in a particular area (de L. Dantas et al. 2013; Rotter and Rebertus 2015).

Furthermore, in their study across three continents, (Torello-Raventos et al. 2013) conclude that floristic and stand structure play a significant factor in the meaningful delineation of tropical vegetation formations, especially when discussing the forest-savanna transition zone. Savanna and true (i.e. treeless) grasslands are commonly found in lowland parts of the tropical landscape. Mount Rinjani National Park is a part of tropical climate region of Lombok Island in West Nusa Tenggara, Indonesia that consists of various types of ecosystems ranging from lowland tropical rain forests, mountainous tropical forests to sub-alpine vegetation. However, Mount Rinjani demonstrates that savanna and grassland also exist at high altitudes. Grasslands that occur on mountains can be formed due to fire (van Steenis et al. 2006). Subsequently, fire and grazing are commonly known factors that sustain the grassland and prevent it from shifting to another state (van Steenis et al. 2006). Studies on the diversity of flora species within the forests of Mount Rinjani have been carried out, but most of this research has focused on the hiking trail to the summit (Kurniawan et al. 2012; Wardani et al. 2012; Tobe et al. 2010; Mahakam et al. 2019) including a vegetation inventory on this part of the forest (Mansur 2016). Studies of the savanna and the forestsavanna transition zone are limited. The objectives of this research paper are to evaluate the evidence for the existence of forest-savanna transition zones on Mt. Rinjani. The savanna-forest formation in Rinjani National Park is considered important in terms of understanding the formation and maintenance of high elevation savanna.

\section{MATERIALS AND METHODS}

The study was conducted on Mt. Rinjani, Lombok Island, West Nusa Tenggara, Indonesia, at an altitude of $1,386 \mathrm{~m}$ above sea level (Figure 1). Cross-checking the study area was with a fire map based on the MODIS burnt area, which confirmed approximately 12 years of fire absence. However, there were signs of recent small-scale fire in the field that perhaps were not detected by MODIS. Six line transects were laid out across forest-savanna transition. Five sampling plots $\left(\begin{array}{llll}50 & \text { x } & 50 & \mathrm{~m}^{2}\end{array}\right)$ were established along each transect. Distances between transects were at least $100 \mathrm{~m}$. Therefore, there were 30 plots of $50 \times 50 \mathrm{~m}^{2}$ in size for each plot in total. In each of the $50 \times 50 \mathrm{~m}^{2}$ plots, we had smaller plots of $5 \times 5 \mathrm{~m}^{2}$ nested randomly. We record abundance, stem diameter, height of woody species, and abundance of groundcover species in each smaller plot. We also recorded local environmental data, namely soil variables (soil $\mathrm{pH}$ and soil moisture), local microclimate (light intensity, air temperature, relative humidity, and wind velocity and heat stress index), and topography (altitude and slope) in each plot.

The species turnover (beta diversity) along transects plots was calculated to indicate location of the boundary within the transition zone using a modified Sorensen's community correspondence index, CCI (Barbour et al. 1980; Cook et al. 2005), using the formula:

$$
\mathrm{CCI}=\frac{2 \mathrm{c}}{a+b}
$$

Where; a: the number of species present in the first community, b: the number of species present in the second community, and c: the total number of species found in both communities. We then calculate $\mathrm{D}$, which is an index of how much a species list changes across sites with the formula as follows (Cook et al. 2005):

$$
D=1-\mathrm{CCI}
$$

This index ranges from 0 to 1 , with a low value indicating little change in the species composition between sites, whereas a high value indicates the opposite. We then plotted $D$ with the distance along transect, to determine points where species composition changes dramatically (van Etten 1987).

Various indicators were used to detect whether the boundary is advancing or retreating in the direction of a specific ecosystem (forest or savanna) (Hennenberg et al. 2005; Hoffmann et al. 2012). If progressively less dense but younger tree cover with distance into savanna (i.e. abundant occurrence of saplings and seedlings) is observed, then this is evidence of forest spreading. Conversely, if tree density is greater and trees are older or larger at the boundary, it suggests either a stable or retreating forest. The Importance Value Index (IVI) is used to measure species dominance for this purpose because it fairly compares each stratum with different sized plants. 


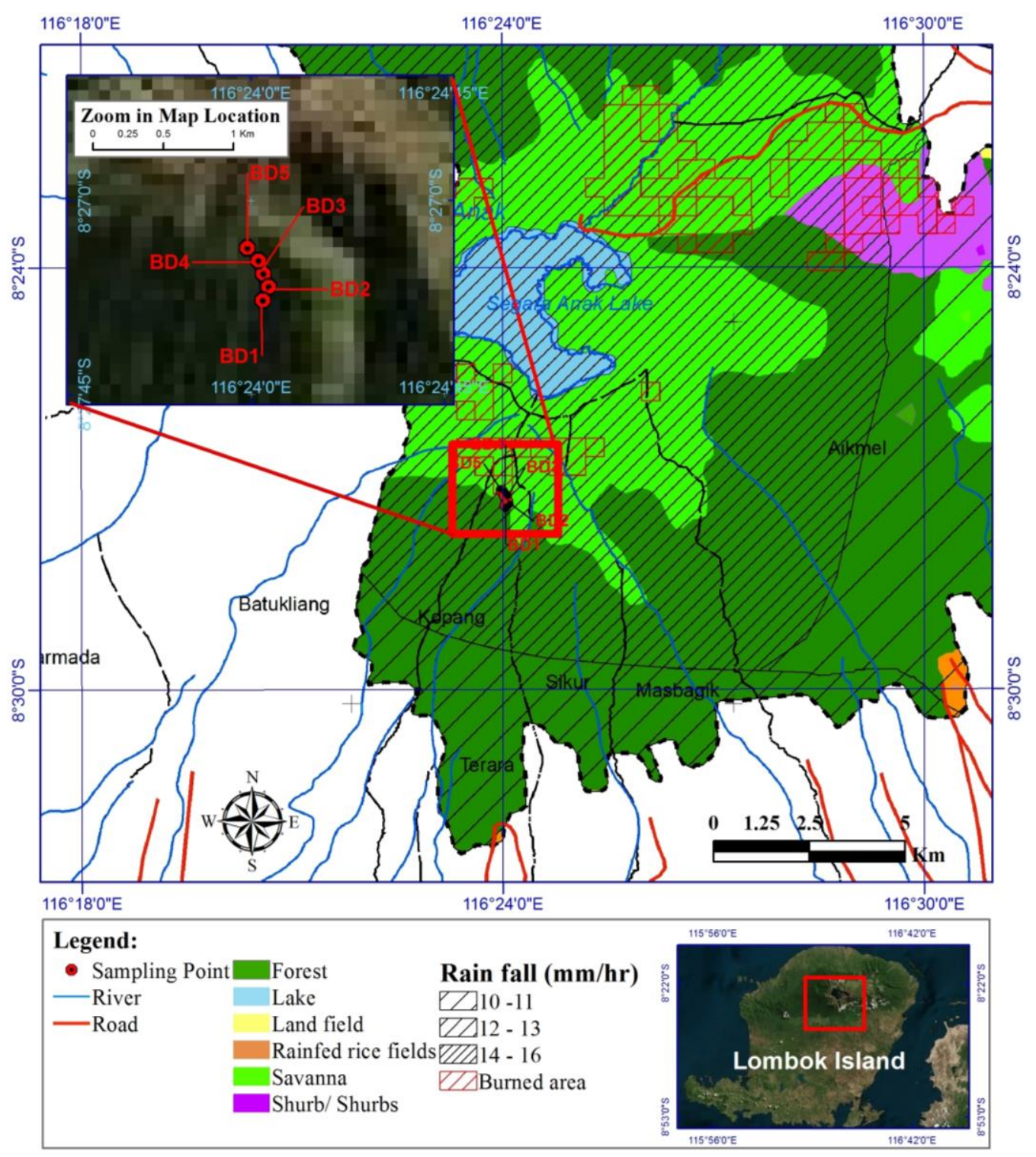

Figure 1. Study area (red square) in Mt. Rinjani, Lombok Island, West Nusa Tenggara, Indonesia, with location of transects shown in inset. (source: Modis 2000-2013 and Mount Rinjani National Park map)

Importance Value Index for each stratum (trees, poles, sapling, seedling, and groundcovers) was calculated using the formula from Kent (2011). The composition of tree species can also provide evidence of boundary dynamics. For instance, if typical rainforest tree species are more likely found in the savanna close to the boundary, it suggests that forests are spreading. Analysis of Similarity (ANOSIM) was used to detect any floristic and environmental differences between savanna, forest, and boundary plots. A one-way ANOSIM (analysis of similarity) was used for this. ANOSIM is basically analogous to standard univariate ANOVA, and tests $a$ priori defined groups against random groups in ordinate

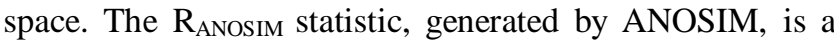
relative measure of separation of the a priori defined groups. A zero (0) indicates that there is no difference among groups, while one (1) indicates that all samples within groups are more similar to one another than any samples from different groups (Clarke 1993).

\section{RESULTS AND DISCUSSION}

Species composition and species turnover changes along transects from forest to savanna are shown in Figure 2. Along these transects, the position where the species turnover rate of trees and groundcovers layers is at the maximum can be readily observed (eg from BD2 to BD3 for forests, and from BD4 to BD5 for savanna; Fig. 2). This is likely representing a narrow transition zone or a sharp boundary between forest and savanna. Species composition in the transition zone (based on highest IVI results) comprises Ficus septica, Macaranga tanarius, Lindera sp., Engelhardia spicata, Saurauria sp., Rytidosperma 
penicillatum, and Athyrium sp. Some species such as Ficus septica, Macaranga tanarius, Lindera sp., Engelhardia sp. dominate in the mountain zone (Mansur 2016). The first four of these are typical forest tree species as found in our plot sampling. In contrast, Saurauria sp., Rytidosperma penicillatum, and Athyrium sp. are typical savanna' species (Mansur 2016; Rozak and Setiadi 2016).

Figure 3 shows Non-metric Multi-Dimensional Scaling analysis (NMDS) and Analysis of Similarity (ANOSIM) results of species composition and microclimate data within forest, forest-savanna boundaries (borders), and savanna. Non-metric multidimensional scaling (NMDS) of the Bray-Curtis species similarity of all three sites showed clear floristic separation between savanna and forest, and between savanna and border, but not between forest and border. The global test of Analysis of Similarity showed that at a significance level of $P<0.5 \%$ and a global $R$ value of 0.62 , there were significant differences in BrayCurtis species similarity between the sites. The NMDS based on environmental data showed clear separation between savanna and forest only.

Mount Rinjani is an active volcano that is undergoing primary succession in most parts of its south-west slope. However, once grasses were vastly formed, only a small number of tree species can grow, perhaps due to high competition for resources with grasses and the absence of shading (Afrianto et al. 2016). Clumps of trees formed a small "island" of forest found in the crevices and steep gullies on the mountain's southwest slope (Figure 4). The clumps of trees or small areas of forest/forest patches can establish in the crevice perhaps due to microclimate conditions that benefit the seeds of tree species. In this landscape, forest is often constrained to geomorphic/ topographic conditions that protect sites from fire (RussellSmith et al. 2012). Steep gullies have been proven to only be fire protected but can also provide soils with higher water availability and they develop not too extreme microclimates (Murphy and Bowman 2012).

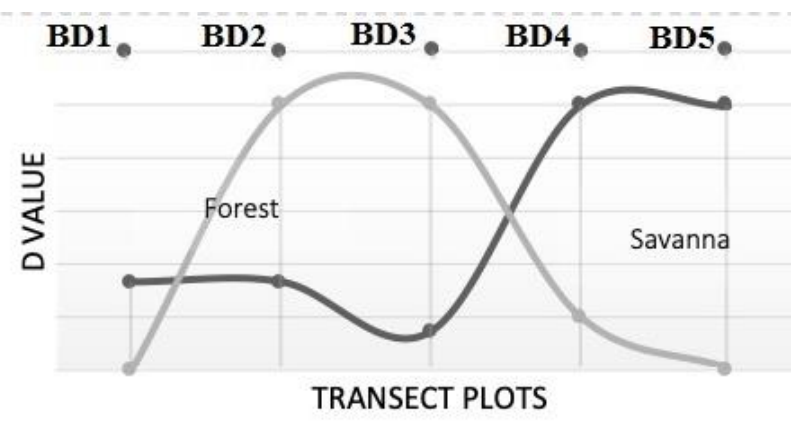

$\longrightarrow$ Spec turnover (tree) $\longrightarrow$ Spec turnover (groundcov)

A

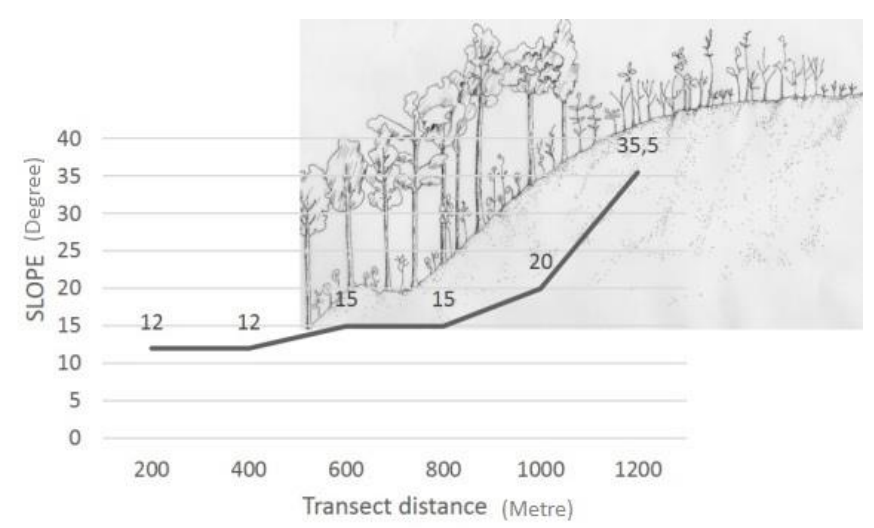

$\mathbf{B}$

Figure 2. A. Species turnover rates (D value) between forest-transition-savannas in Rinjani National Park, Lombok Island, Indonesia, where BD is code used for plots. B. Transect topography and a sketch of profile diagram for sample sites at Rinjani National Park
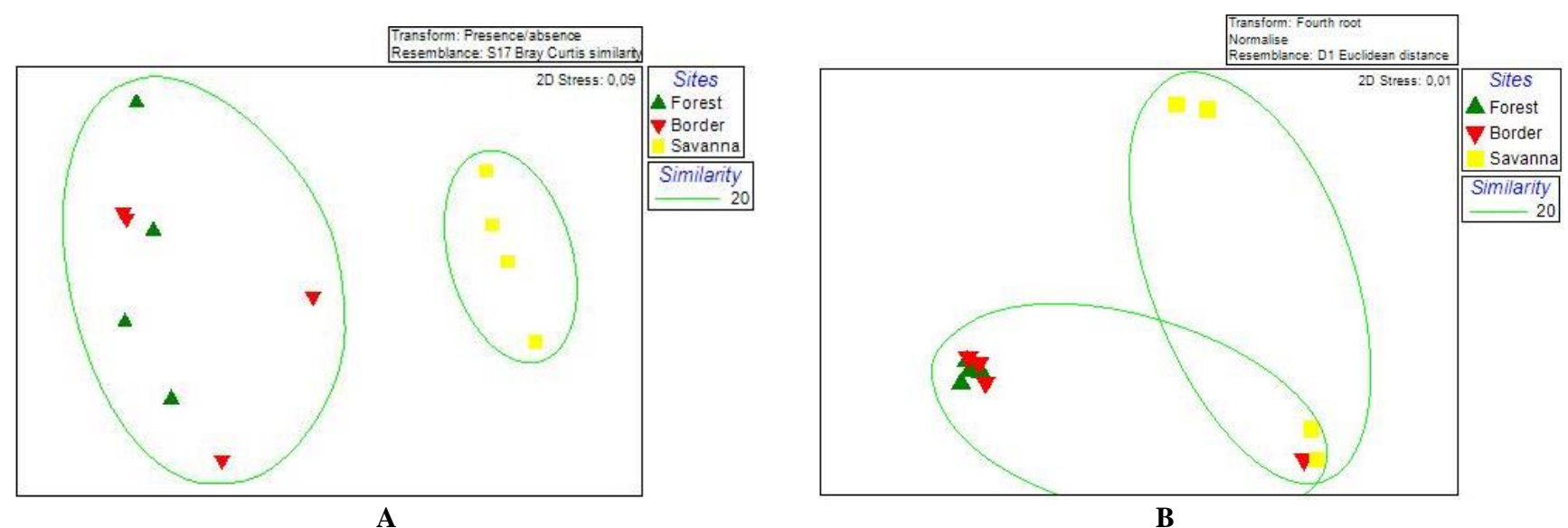

Figure 3. A. NMDS ordination analysis of sampled sites based on Bray-Curtis similarity (species presence-absence) in Rinjani National Park, Lombok Island, Indonesia. ANOSIM Global R statistic 0.62. Pairwise test of Forest-Boundary $R_{\text {stat }}=-0.21$, Forest-Savanna $R_{\text {stat }}=$ 1 , Boundary-Savanna $R_{\text {stat }}=0.81$. B. NMDS ordination analysis of environmental data of the sampled sites based on Euclidian distance. ANOSIM Global R statistic 0.26. Pairwise test of Forest-Boundary $R_{\text {stat }}=0.03$, Forest-Savanna $R_{\text {stat }}=0.57$, Boundary-Savanna $R_{\text {stat }}=0.17$ 


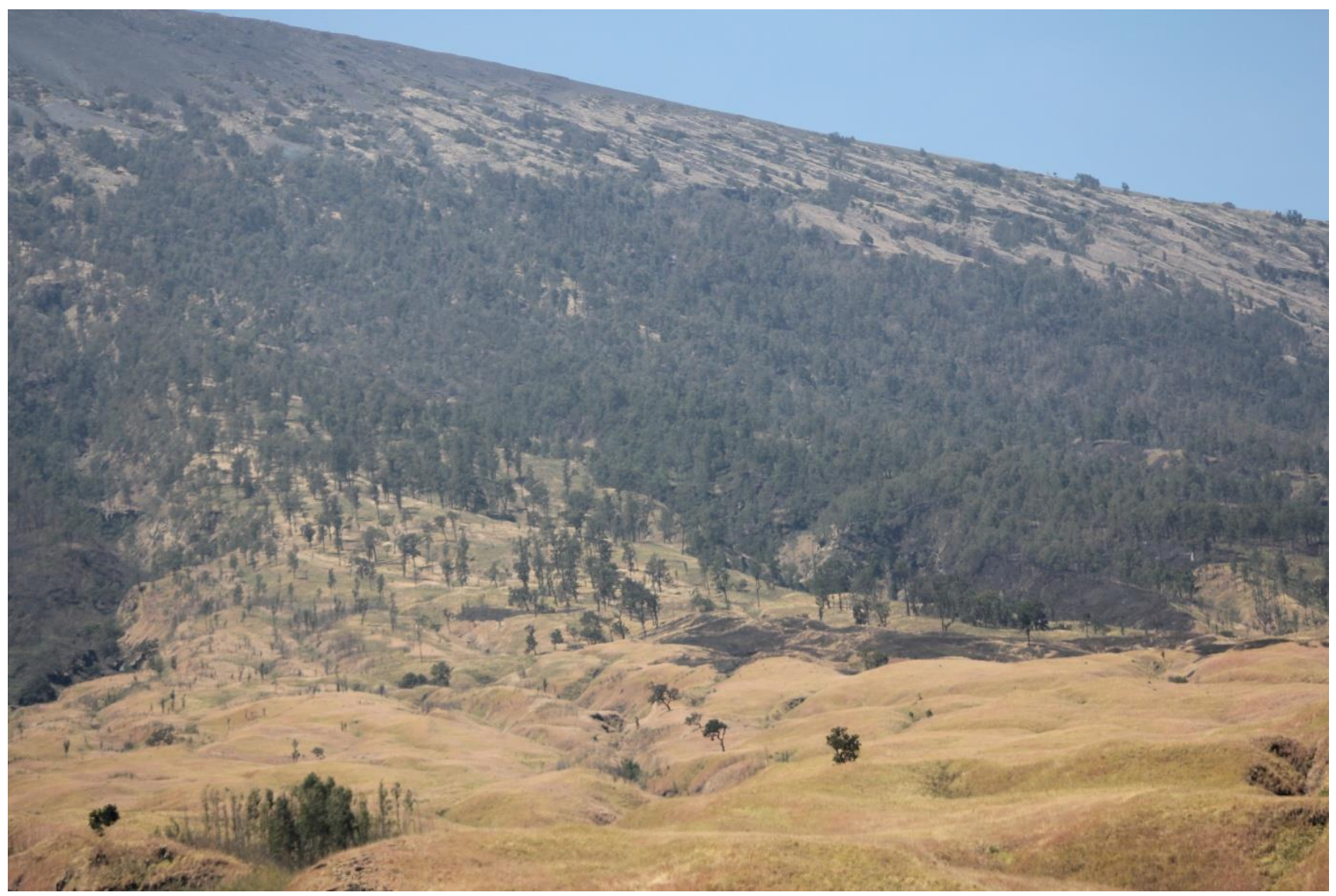

Figure 4. Landscape of the Mt. Rinjani Savanna, Lombok Island, Indonesia, and forest. "Clumps" of trees exist on a crevice and gullies due to the landscape feature of the mountain slope

On Mt. Rinjani National Park, the forest and the savanna boundary is a somewhat sharp boundary. Sharp boundaries can be driven by differences in factors such as fire, soil, and geomorphic characteristics between the forest and the savanna (Hoffmann et al. 2012). There were signs of recent fire evidence at the sampled sites in our study, particularly in the savanna. There were also considerable changes in soil $\mathrm{pH}$, soil moisture, and slope between the measured plots from forest interior to the savanna boundary. For instance, soil pH shifted from 6.1 to 6.8 going from forest to savanna. Similarly, soil moisture declined from $30 \%$ to only $10 \%$. Slope of the area also shifted from $12^{\circ}$ to $35^{\circ}$. Therefore it can be concluded that the forest-savanna boundary on Mt. Rinjani is primarily linked with discontinuities in edaphic, topographic, and geomorphic factors across the landscape, it may also be linked with the effect of fire. However, the role of fire in contributing to the sharpness of the boundary cannot be discounted given fire in the transition zone would likely kill mainly forest tree species, especially their saplings and seedlings.

The zone of transition or boundary on Mt. Rinjani is also characterized by a change in species composition from forest tree species and savanna species. This boundary or border area is floristically made up of forest and savanna species. In terms of dynamic of this boundary, it seems that there is sign of forest expansion. Ordination result indicates this by showing that boundary plots resembled forest plots. Evidence of forest species presence in a form of saplings such as Macaranga tanarius, Engelhardia spicata, and Ficus sp in the boundary may also further confirm this conclusion.

This overview of boundary on Mt. Rinjani suggests that determination of the location(s) of boundary between forest and savanna can be done through field observations. However, integration of field-based observations and remote sensing applications may deliver a more complete picture at the landscape scale and over wider timeframes. Micro- and macro-environmental factors, as well as, fire disturbance, are also significant components in the forestsavanna boundary on Mt. Rinjani. Fire, or rather absence of it, is playing an important role in determining the distribution of forest species where it can be seen in patches within the savanna-dominated landscape. Advance of forest rather than savanna on the Mt. Rinjani south-west slope may indicate that the boundary is dynamic, spreading where fire has been absent for some years. Furthermore, this dynamic may have implications to supporting the argument that savanna is not a climax and stable state instead it is a transitional (Abades et al. 2014). Forest expansion on Mt. Rinjani may also indicate that the primary succession is not completely arrested, but rather it is a progressive or stepped succession. 


\section{ACKNOWLEDGEMENTS}

The authors would like to thank Rufford Foundation and Edith Cowan University for supporting the research. Thank also goes to the Mount Rinjani National Park director, and park rangers, and PEH for the data and field assistance.

\section{REFERENCES}

Abades S, Gaxiola A, Marquet PA. 2014. Fire, percolation thresholds and the savanna forest transition: a neutral model approach. J Ecol 102: 1386-1393.

Adejuwon JO, Adesina FA. 1992. The nature and dynamics of the forestsavanna boundary in south-western Nigeria. In: Adesina JO, Adesina FA (eds.) Nature and Dynamics of Forest-Savanna Boundaries. Chapman and Hall, London.

Afrianto W, Hikmat A, Widyatmoko D. 2016. Komunitas floristik dan suksesi vegetasi setelah erupsi 2010 di Gunung Merapi Jawa Tengah. Jurnal Biologi Indonesia 12 (2): 265-276. [Indonesian]

Barbour MG, Burk JH, Pitts WD. 1980. Terrestrial Plant Ecology. The Benjamin Cummings Publishing Company Inc., California.

Clarke KR. 1993. Non-parametric multivariate analyses of changes in community structure. Austr J Ecol 18: 117-43.

Cook WM, Yao J, Foster BL, Holt RD, Patrick LB. 2005. Secondary succession in an experimentally fragmented landscape: community patterns across space and time. Ecology 86 (5): 1267-1279.

de L Dantas, V, Batalha MA, Pausas JG. 2013. Fire drives functional thresholds on the savanna-forest transition. Ecology 94 (11): 2454 2463.

Gardner TA. 2006. Tree-grass coexistence in the Brazilian cerrado: demographic consequences of environmental instability. J Biogeogr 33 (3): 448-463

Hennenberg KJ, Goetze D, Kouamé L, Orthmann B, Porembski S. 2005. Border and ecotone detection by vegetation composition along forestsavanna transects in Ivory Coast. J Veg Sci 16 (3): 301-310.

Hoffmann WA, Geiger EL, Gotsch SG, Rossatto DR, Silva LCR, Lau OL, Haridasan M, Franco AC. 2012. Ecological thresholds at the savannaforest boundary: How plant traits, resources and fire govern the distribution of tropical biomes. Ecol Lett 15 (7): 759-768.

Kent M. 2011. Vegetation Description and Data Analysis: A Practical Approach. 2nd ed. John Wiley \& Sons, New York.

Klink CA. 2014. Policy intervention in the Cerrado Savannas of Brazil changes land use and effects on conservation. In: Adriana GCM, Eliana FS (eds.). Ecology and Conservation of The Maned Wolf: Multidisciplinary Perspectives. CRC Press, Brazilia

Kurniawan S, Nasriyanto AB, Supriyanto, Budi ASE, Mertha IG. 2012. Buku Panduan Pengenalan Jenis Pohon di Sepanjang Jalur Pendakian Taman Nasional Gunung Rinjani. Kementerian Kehutanan Dirjen PHKA, Balai Taman Nasional Gunung Rinjani, Mataram, Lombok. [Indonesian]

Mahakam I, Aji L, Rini DS, Webliana K. 2019. Pemanfaatan Kawasan Hutan dengan Tujuan Khusus (KHDTK) Senaru. Transformasi. Jurnal Pengabdian Masyarakat 15 (1): 53-60. [Indonesian]

Mansur M. 2016. Struktur dan komposisi jenis-jenis pohon di Taman Nasional Gunung Rinjani bagian selatan, Lombok, Nusa Tenggara Barat. Jurnal Biologi Indonesia 12 (1): 87-98. [Indonesian]
McLean RC. 1919. Studies in the ecology of tropical rain forest: With special reference to the forest of South Brazil. J Ecol 7: 5-54.

Mews HA, Pinto JRR, Eisenlohr PV, Lenza E. 2014. Does size matter? Conservation implications of differing woody population size with equivalent occurrence and diversity of species for threatened savanna habitats. Biodivers Conserv 23 (5): 1119-1131.

Murphy BP, Bowman DM. 2012. What controls the distribution of tropical forest and savanna? Ecol Lett 15 (7): 748-758.

Pennington RT, Lehmann CER, Rowland LM. 2018. Tropical savannas and dry forests. Curr Biol 28 (9): 541-545.

Pérez-García EA, Meave JA. 2006. Coexistence and divergence of tropical dry forests and savannas in southern Mexico. J Biogeogr 33 (3): 438-447.

Porensky LM, Wittman SE, Riginos C, Young TP. 2013. Herbivory and drought interact to enhance spatial patterning and diversity in a savanna understory. Oecologia 173 (2): 591-602.

Rotter MC, Rebertus AJ. 2015. Plant community development of Isle Royale's moose-spruce savannas. Botany 93 (2): 75-90.

Rozak AH, Setiadi T. 2016. Modeling of tree growth after forest fire in Mount Ciremai National Park, Indonesia. Biotropia 2 (2): 65-73.

Russell-Smith J, Edwards AC, Price OF. 2012. Simplifying the savanna: the trajectory of fire-sensitive vegetation mosaics in northern Australia. J Biogeogr 39 (7): 1303-1317.

Smith WG. 1914. Notes on Danish vegetation. J Ecol 2: 65-70.

Sutomo. 2013. Ecological succession on volcanic ecosystem of Mount Merapi Indonesia and its implication for restoration. SEAMEOBIOTROP, Bogor. [Indonesian]

Tobe H, Shinohara W, Utami N, Wiriadinata H, Girmansyah D, Oginuma K, Azuma H, Tokuoka T, Kawaguchi E, Kono M, Ito M. 2010. Plant diversity on Lombok Island, Indonesia: an approach at identification using DNA barcodes. Acta Phytotax Geobot 61 (2): 93-108.

Torello-Raventos M, Feldpausch, TR, Veenendaal E, Schrodt F, Saiz G, Domingues TF, Djagbletey G, Ford A, Kemp J, Marimon BS, Junior BHM, Lenza E, Ratter JA, Maracahipes L, Sasaki D, Sonké B, Zapfack L, Taedoumg H, Villarroel D, Schwarz M, Quesada CA, Ishida FY, Nardoto GB, Affum-Baffoe K, Arroyo L, Bowman DMJS, Compaore H, Davies K, Diallo A, Fyllas NM, Gilpin M, Hien F, Johnson M, Killeen TJ, Metcalfe D, Miranda HS, Steininger M, Thomson J, Sykora K, Mougin E, Hiernaux P, Bird MI, Grace J, Lewis SL, Phillips OL, Lloyd J. 2013. On the delineation of tropical vegetation types with an emphasis on forest/savanna transitions. Plant Ecol Divers 6 (1): 101-137.

van der Maarel E. 1990. Ecotones and ecoclines are different. J Veg Sci 1: 135-138.

van Etten EJ. 1987. Environmental factors affecting the boundary between mulga (Acacia aneura) and hummock grassland (Triodia spp.) communities. [Thesis], Curtin University of Technology, Australia.

van Steenis CGGJ, Hamzah A, Toha M. 2006. Mountain Flora of Java 2nd ed. Brill Academic Publishers, Leiden, Boston.

Walker LR, Walker J, del Moral R. 2007. Forging a new alliance between succession and restoration. In: Walker LR, Walker J, Hobbs RJ (eds.) Linking Restoration and Ecological Succession. Springer, New York.

Walker RL, del Moral R. 2003. Primary Succession and Ecosystem Rehabilitation. Cambridge University Press, UK.

Wardani W, Hidayat A, Tihurua EF, Kartonegoro A, Sulistyaningsih LD, Kuncari ES, Walujo EB. 2012. Endemic plants of Mt. Rinjani: an outlook to the conservation strategy. Floribunda 4 (5): 107-112.

Zahawi RA, Augspurger CK. 1999. Early plant succession in abandoned pastures in Ecuador. Biotropica 31: 540-52. 